\title{
Long-run urban dynamics: understanding local housing market change in London
}

Article

Accepted Version

Gibb, K., Meen, G. and Nygaard, C. (2019) Long-run urban dynamics: understanding local housing market change in London. Housing Studies, 34 (2). pp. 338-359. ISSN 02673037 doi: https://doi.org/10.1080/02673037.2018.1491533 Available at https://centaur.reading.ac.uk/77794/

It is advisable to refer to the publisher's version if you intend to cite from the work. See Guidance on citing.

To link to this article DOI: http://dx.doi.org/10.1080/02673037.2018.1491533

Publisher: Taylor \& Francis

All outputs in CentAUR are protected by Intellectual Property Rights law, including copyright law. Copyright and IPR is retained by the creators or other copyright holders. Terms and conditions for use of this material are defined in the End User Agreement.

\section{www.reading.ac.uk/centaur}

\section{CentAUR}

Central Archive at the University of Reading

Reading's research outputs online 


\title{
Long-Run Urban Dynamics: Understanding Local Housing Market Change in London
}

\author{
Kenneth Gibb (Urban Studies, School of Social and Political Sciences, University of Glasgow, Bute \\ Gardens, Glasgow G12 8RS, UK; email ken.gibb@glasgow.ac.uk ) \\ Geoffrey Meen ( Department of Economics, University of Reading, Whiteknights, Reading, RG6 6AA, UK; \\ email g.p.meen@reading.ac.uk ) \\ Christian Nygaard (Centre for Urban Transitions, School of Arts, Social Sciences and Humanities, \\ Swinburne University of Technology, John Street, Hawthorn, \\ Victoria 3122 Australia; email anygaard@swinburn.edu.ac)
}

\section{Abstract}

Recently, a literature has emerged using empirical techniques to study the evolution of international cities over many centuries; however, few studies examine long-run change within cities. Conventional models and concepts are not always appropriate and data issues make long-run neighbourhood analysis particularly problematic. This paper addresses some of these points. First, it discusses why the analysis of long-run urban change is important for modern urban policy and considers the most important concepts. Second, it constructs a novel data set at the micro level, which allows consistent comparisons of London neighbourhoods in 1881 and 2001. Third, the paper models some of the key factors that affected long-run change, including the role of housing. There is evidence that the relative social positions of local urban areas persist over time but, nevertheless, at fine spatial scales, local areas still exhibit change, arising from aggregate population dynamics, from advances in technology, and also from the effects of shocks, such as wars. In general, where small areas are considered, longrun changes are likely to be greater, because individuals are more mobile over short than long distances. Finally, the paper considers the implications for policy.

Keywords: persistence; social status; institutions; local dynamics. 


\section{Long-Run Urban Dynamics: Understanding Local Housing Market Change in London}

\section{Introduction}

Cities are the product of multiple cycles of construction and reconstruction, which affect the spatial distribution of poverty and affluence. There is, however, now a significant body of evidence that the origins of many modern urban problems can be traced to historical roots and that historic urbanisation has conditioned the subsequent development path of neighbourhoods. At fine spatial scales processes of development and redevelopment are not always evident in equal measures, nor are the processes of change necessarily uniform or symmetric. For example, Orford et al (2002) found a high degree of persistence in the spatial distribution of poverty in London between 1896 and 1991. Dorling et al (2000) indicate that local London poverty levels in the late $19^{\text {th }}$ century are a slightly better predictor of some contemporary health problems, notably strokes and cancers, than current levels of deprivation, perhaps indicating the importance of early life conditions. Moreover, by the mid-19 ${ }^{\text {th }}$ century, segregation had become a feature of the major British cities. Cannadine (1977) points to three factors: first, strong population growth in the first half of the century; second, concentrated land rights allowed owners to enforce a form of land-use planning and, third, the tastes of middle-class households for suburban living also promoted segregation, because cheap rail fares for the working classes were not established until later; poorer households still had to rely on walking to walk.

Since Roman times, London has always been the dominant city in Britain. Around the opening of the $16^{\text {th }}$ century, the capital had a population of approximately 50,000 ; by 1650 , it was the second largest city in Europe (after Paris) with a population of 350,000. But, by 1800, London had outstripped Paris with approximately 1 million residents and by the First World War, Inner London's population stood at approximately 4.5 million. Unsurprisingly, London's housing was unable to keep pace with the population increase, leading to the well-documented over-crowding and rookeries in the worst parts of the capital, summarised, for example, in Charles Booth's poverty maps. After the First World War the population of Inner London declined and reached its lowest point in the 1981 census at approximately 2.5 million. As London's population has since recovered and the wealth of the capital has grown, further changes have again taken place. It would be surprising if these large aggregate 
cyclical and structural changes were not accompanied by changes in the spatial distribution of social structures, not least because of the changes in transport infrastructure and the effects of the Second World War, but at the local level the articulation of change may nevertheless vary significantly.

Therefore, this paper illustrates the importance of the long run for the analysis of urban dynamics. London is chosen because it is the largest British city, but the principles are also relevant to other cities. The long-run is important for empirical analysis because, typically, major structural changes take place rarely and are not captured in short-run data sets. Furthermore, by the mid-19 ${ }^{\text {th }}$ century, London's population was growing strongly and patterns of neighbourhood segregation had become established; improvements in data quality allow the changes to be analysed more formally. Overall, the paper examines some of the key factors, particularly related to housing markets that promoted or hindered long-run local change. Section 2 takes Kensington as a case study to illustrate some of the central issues; it is also includes the area of the Grenfell Tower disaster. In Section 3, the wider conceptual issues are brought out, relevant to the subsequent empirical material in Sections 4 and 5, using new micro household data on intra-urban dynamics. Section 5 models some of the factors that contribute to changes in social status over long time periods. Section 6 draws out the implications for modern policies.

\section{The $19^{\text {th }}$ Century Origins of Grenfell Tower}

Grenfell Tower is located in the west London borough of Kensington and Chelsea; the borough as a whole has the highest house prices in the country (an average price of $£ 0.5$ million), but some northern parts of the borough have a housing stock in which more than $70 \%$ of households are social tenants. Until the early $19^{\text {th }}$ century, Kensington was largely rural ${ }^{1}$. However, its nature changed, initially through the construction of canals and later with the arrival of railways. The advances provided the impetus for speculative property development. South Kensington became a high-class residential area of villas and large terraced properties. The 52 acre Norland Estate provided a good example, where building began in 1839 and was largely completed in the next twelve years, except for the northern part of the estate, where the lot sizes were smaller.

\footnotetext{
${ }^{1}$ See www.rbkc.gov.uk/vmhistory/general/default.asp for more details.
} 
Comparing the Norland Estate with the Booth classification at the end of the century, none of the estate lies in Booth's wealthy areas, but neighbouring Notting Hill to the east and Holland Park to the South East were both wealthy. Rather the majority of the estate was well-to-do middle class, fairly comfortable or mixed. But the northern part of the estate, where the dwellings were smaller, had significant concentrations of the lowest classes. Slightly further to the north lay Notting Dale - the later site of Grenfell Tower - and its name gives an indication of its potential problems. Whereas wealthy Notting Hill and Holland Park lie approximately 29 metres above sea level (Figure 1 is taken from the peak of the Hill), Notting Dale is only 8 metres; the building of quality dwellings on high ground is common, partly because of the view and partly because such areas were less liable to flooding. In addition, the soil in the Notting Dale area was composed of clay, which was particularly good for brick making. However, Woodward's (1906) classification of London's soils for their building suitability indicates that London clay suffered from its low elevation and greater water content, leaving the ground prone to long spells of dampness and cracking in dry conditions.

\section{[insert Figure 1 about here]}

In the early $19^{\text {th }}$ century groups of brick makers and pig-keepers moved into the area; Booth's classification of the Notting Dale area shows a concentration of the very poor, although this is, by no means, exclusively the case. Grenfell Road, in fact, existed in the late $19^{\text {th }}$ century and is classified in Booth's notebooks as fairly comfortable.

After the First World War, fewer middle-class households employed servants needed in the larger villas and the large houses of Notting Hill became less attractive. The area declined in status and houses were subdivided. It was against this background that the 24-storey Grenfell Tower (and other blocks) formed part of wide-spread slum clearance activities. The tower was built between 1972 and 1974. But, as inner London's population began to expand again, the larger $19^{\text {th }}$ century properties of Notting Hill became more attractive and the Hill and surrounding areas became gentrified. In contrast to the Dale, the distinguishing feature was the quality of the architecture and the underlying physical soundness of the dwellings. The combination of good quality $19^{\text {th }}$ century dwellings in part of the borough and poorer-quality housing in the remaining part has been a crucial influence in the continuation of the patterns of wealth and deprivation observed almost two hundred years earlier. 
A number of issues stand out: first, the dynamics of local areas are not independent of wider trends, notably the displacement of population to suburban areas that took place for large parts of the $20^{\text {th }}$ century and the subsequent reversal of those trends. Second, soil and elevation provided the initial conditions for the segregation of rich and poor households, which have subsequently proved difficult to change. Kensington provides one example. But, even in Kensington, it is not the case that a discrete divide exists; rather the quality of the dwellings changes gradually from the peak of the hill. Third, external shocks such as wars may have significant effects on the population distributions - Notting Dale was bombed, but this is even more evident in the East End of London, which was more heavily bombed than the west (see Meen et al 2016, Chapter 9). More generally, large shocks appear to be necessary to promote fundamental change. Finally, change appears to be more associated with technology, for example rail and transport networks, than direct housing policies.

\section{Issues and Concepts from the Literature}

Urban economists have long recognised the importance of history for current economic conditions and policy possibilities. McDonald and McMillen (2007) stress the importance of economic history as an important tool that can 'combine analyses of the institutions and historical context of the urban area...to provide a convincing narrative of what happened and why. The explanation may have considerable relevance for current policy development' (p.485). The conceptual approaches that underpin our analysis start with neo-classical urban economic analysis but, taking this historical perspective seriously (and also being pragmatic in that we wish to wed operational conceptual frameworks to specific case study data), lead us into wider modes of analysis. The three main processes that operate at intra-urban levels are: path dependency, social interactions and institutions. We look at these, briefly, in turn, but start by asking why it is difficult to undertake intra-urban analysis with conventional neo-classical tools alone?

Conventional approaches employing neo-classical urban housing economics have a long and wellestablished pedigree, stressing the importance of spatial, physical and neighbourhood characteristics (for instance in hedonic urban house price models). Traditionally, they did not focus on historical dimensions, though this has altered in recent decades. Urban economic models have focused on density gradients over urban space, agglomeration economies and the accretion of additional elements to the monocentric model in order to account for key temporal dynamic features such as the durability or longevity of the housing stock (surveyed by Brueckner, 2000). Fundamental first 
causes of geographic location of cities have in this literature been tied down to either natural geographic advantages (Baumont and Huriot, 1998) or to random shocks (Arthur, 1994).

A continuing defence of the monocentric model (Cheshire and Shepherd, 1995, 1998) argues that the distance to the centre still matters, albeit in a more extensive monocentric model type and with flattened rent gradients reflecting falling transport costs, but they recognise that such models need to better capture intra-urban or neighbourhood variation and economic and social processes therein. This speaks also to the social patterning of households by income or wealth stratified across urban space, which may itself reflect long-term patterns that persist and cannot be wholly explained by the income elasticity of housing space.

What are the alternative conceptual frameworks that might help make sense of these long-term intraurban processes? We focus here on three: path dependency, social interactions and institutions - and stress that, as we shall see, they are certainly not, to our thinking, independent of each other but rather overlap.

We can readily see this complementarity. Path dependency in an urban setting can be thought of as the constraints on decision-making by households, firms and governments that arise from the inherited structure of the built environment and the underlying available technology (Meen et al 2016, p.8). Over time, prevailing spatial structures persist because non-malleability of the local built environment and property rights (ie institutions) limit and/or systematically skew the choices sets available to economic agents. The only slowly changing physical infrastructure of our cities, decided decades or generations ago, readily constrain current household housing decision-making. This persistence across neighbourhoods may also be created and reinforced by group networks (e.g. migrants living with their own in specific small area clusters), which are an important form of social interaction helping to reinforce these persistent patterns, or conspicuous consumption aspects of housing and locational choice.

While the three processes complement each other they also raise the prospect that spatial adjustments over time are likely to be asymmetric and promote the persistence of segregation. For instance, endogenous institutional reproduction and innovation may have differential effects across areas with different socio-economic or morphological characteristics. Moreover, in market based 
housing systems, location and access are less constrained choices for higher income groups than lower income groups.

\section{Path Dependency}

It is helpful to formalise our thinking of path dependency, which is a process wherein the evolution of the process is determined by its own history. One could say 'constraints on the choice set of the present...are derived from historical experiences of the past (North, 2005, p.52). Evolutionary economic geography further emphasises the probabilistic, rather than deterministic, conditioning nature of path dependency (Martin 2010).

Arthur (1994) usefully distinguishes between ergodic and non-ergodic processes. A dynamic process is said to be ergodic if different sequences of historical events lead to the same market outcome. In other words, ergodic processes are not path dependent. On the other hand, a non-ergodic stochastic process can be defined (David, 2007) in terms of the limiting probability distribution which governs the dynamics of the process and is path dependent (Taleb, 2018, distinguishes ergodic and nonergodic processes to better understand the risks of uncertain outcomes). In terms of neighbourhood and social status over time this means that once an area's social status is established it is likely to remain anchored to that status in subsequent periods. Krugman (1991) notes that adjustment in terms of mobility decisions may be slowed (relative to 'optimal' outcomes) because of adjustment or transactions costs.

Arthur (1994) uses Polya processes as a way of developing stochastic systems exhibiting nonergodicity, to explain how spatial agglomerations arise (in a way that is completely different from the neo-classical explanations of city development outlined above). An important aspect of this approach is that it suggests that random initial shocks determine which of a possible set of outcomes is arrived at over time. This process is ex ante non-predictable and is irreversible. While we cannot in advance predict or identify such path dependencies, the question not unreasonably arises as to how one can operationalise these ideas? One pragmatic approach (adopted in Meen et al 2016) is to look for major shocks and policy changes that can be modelled over long data series in a given spatial setting. 


\section{Social Interactions}

Neighbourhoods also comprise endogenous social interactions between local residents, which are not simple to understand or analyse. We do, however, know from numerical simulations that it is probable that integrated communities of rich and poor are unstable (stochastically) and can readily break down, leading to segregation. We also know that neighbourhoods change slowly but when they do change it can happen suddenly and swiftly (described as phase transitions). Work in cellular automata frameworks signifies the importance of social networks in urban space. For instance, Meen and Meen (2003) working with simple plausible assumptions find that individual random locational choices can quickly tip areas into gentrification processes and that this can happen suddenly.

These threshold, tipping and phase transition processes characteristic of social interactions can also be usefully applied to models that are characterised by S-shaped distributions. Here, the idea is that following a phase transition in a given local area, the residents are now locked-in to a new equilibrium which will persist in the absence of further large enough shocks. For areas at the bottom of the area deprivation ladder with the worst socio-economic scores, it can be challenging for policy and economic market prosperity to unlock these conditions. However, it is one thing to set out a conceptual model for neighbourhood dynamics such as the one sketched above; it remains empirically complex and controversial to be able to actually estimate what is going on. Galster (2010) indicates that there are multiple possible causal pathways to choose from and Manski $(1993,2000)$ identifies a number of empirical problems with neighbourhood effects, which are difficult to distinguish empirically and this matters greatly not just for our conceptual understanding but for the supporting appropriate policy choices open to policy makers.

\section{Institutions}

Institutional analysis may be focused around customs, conventions, habits and norms (often associated with the old institutional economists like Commons and Veblen) or with the more recent new institutional economics of Coase, Williamson and North and focusing on transaction costs, property rights and how they impact on all aspects of economic organisation and behaviour. Both traditions are relevant to our interest in urban persistence and mean reversion from shocks.

North (1994) defines institutions by distinguishing between formal constraints such as rules, laws and constitutions, and informal constraints i.e. norms of behaviour, conventions, self-imposed codes of 
conduct and their enforcement. These institutional constraints taking the form of property rights, social capital, community development, religion, and other exercises of social control and power etc. are important potential sources of both path dependency and mean-reversion following temporary shocks. Meen et al 2016 (chapter 3) give numerous historical examples from the literature about the central role of institutions supporting economic change in the face of large shocks in the form of wars, natural disasters and epidemics as well providing plausible explanations for durable institutional responses to better support societies in the face of these risks.

\section{Empirical Studies of Persistence}

Davis and Weinstein (2002) demonstrate a particularly striking example of spatial persistence by showing significant correlations between Japanese regional population distributions in 6,000 BC and the modern era. Furthermore, they find that, following heavy World War 2 bombings of Japanese cities, population growth rates quickly recovered in the post-war period. Therefore, based on tests from random walk models this major, but temporary, shock appears not to have led to permanent changes to population distributions. More generally, wars have provided useful case studies for persistence tests. Bosker et al. (2007) consider the bombing of German cities in World War 2 and Nitsch (2003) provides evidence of spatial lock-in of population structures in Vienna, following the break-up of the Austro-Hungarian Empire. Dincecco and Onorato (2013) argue that the modern wealthy urban belt that runs from the Low Countries to Northern Italy is related to heavy exposure to wars between 1000 and 1799 .

Epidemics and natural disasters provide further examples of large temporary shocks and Voigtländer and Voth (2013) suggest that the Black Death led to a permanent increase in urbanisation between the $14^{\text {th }}$ and $17^{\text {th }}$ centuries. Pereira (2009) discusses the largest natural disaster to hit Europe - the 1755 Lisbon earthquake - and, despite major short-run GDP losses, argue that the opportunity to reform the economy led to permanent longer-term gains. Similarly, Siodla (2015) and Hornbeck and Kenniston (2017) show that large shocks in San Francisco and Boston temporarily acted as catalysts to negate the effect of durable investments and property rights, enabling areas to re-emerge less constrained by history and more reflective of contemporary economic fundamentals. In these studies coordination failure, institutions and durable investments inhibit dynamic adjustment to economic fundamentals. The empirical evidence at the city and international levels, therefore, suggests that temporary shocks can have permanent long-run effects. Spatial patterns are persistent over time 
unless disturbed by major events and even this is sometimes not sufficient and patterns may revert to the mean.

Empirical tests of long-run persistence are now well established, but all the above studies refer either to international or inter-city differences in performance. None considers persistence in intra-city patterns of poverty and segregation, nor the role of housing markets; this is partly because of the problems of data construction. Empirical studies require consistent information at neighbourhood levels and over long periods of time; the combination is rarely available, although Meen et al (2016) begin to show how such information can be constructed for the three largest cities in the British Empire towards the end of the $19^{\text {th }}$ century, i.e. London, Melbourne and Glasgow. But, as for cities as a whole, a possible feature of long-run local data is that spatial and social structures are persistent, but are subject to infrequent dramatic change; Meen and Nygaard (2011) provide one example for the East End of London. A related fascinating study is provided by Easterly et al (2015), who trace one street block in New York from the $17^{\text {th }}$ century. Nevertheless, more empirical work at the local level is needed.

\section{The Construction of $19^{\text {th }}$ Century Data Sets}

We need to be cautious in assuming that the spatial persistence observed for cities as a whole can be generalised to local areas. Local dynamics can be more volatile, because mobility in the $19^{\text {th }}$ century as well as today is greater over shorter distances (see Ravenstein 1885). A summary of housing-related indicators for the second half of the $19^{\text {th }}$ and early $20^{\text {th }}$ centuries is useful for the next section. The annual reports of the Registrar General of Births, Deaths and Marriages, which were first compiled for 1837/38, are particularly helpful; the Registrar General reported that the average death rate in England and Wales in 1881 was 18.9 per 1000 living persons, but reached 21.3 in London and 25.3 in Glasgow. By contrast, the rate was only 14.2 in Victoria in Australia. Also in 1881 only 2\% of the London population lived in healthy districts (defined as under 17.5 deaths per thousand population). In addition to contemporary reports of the housing conditions of the poor in London (see, for example, Octavia Hill 1866), some of the most graphic descriptions come from fiction; the notorious East London 'Nichol' is represented as 'the Jago' in Arthur Morrison's best-selling novel of East End poverty, $A$ Child of the Jago (1896). 
Population changes were, by no means, equal across areas as shown in Table 1 . The table shows net additions to the housing stock (and so takes account of slum clearances) and population per dwelling as a measure of overcrowding. By the late $19^{\text {th }}$ century, population and construction were heavily influenced by railway development. Acts of Parliament authorising railway construction expanded rapidly from the 1830s and peaked in the 1860s; new Acts declined after this period, but numbers were still significant up to the First World War. From Table 1, which shows a sample of registration districts, in two sub periods 1871-1881 and 1891-1901, expansion took place primarily in the outer suburbs, whereas the inner districts experienced limited gains or even losses. Appendix 1 shows the locations of the inner London districts. The table also shows that, although the population per dwelling was lower in the suburbs than the centre, the rapid expansion of new building in the suburbs up to 1901 only had a limited effect because the growth was accompanied by a similar increase in population, aided by the 1883 Cheap Trains Act.

\section{[insert Table 1 about here]}

By the start of the $20^{\text {th }}$ century slum clearance programmes only had a modest impact on the housing problems of the poorest sections of cities. Table 2 summarises the areas of London cleared under the evolving legislation from the mid-19 ${ }^{\text {th }}$ century until the 1970s. It was not until the 1930s that slum clearances began on a major scale in London, suspended during the Second World War, and tailing off by the mid-970s. Of the 1,190 identified schemes, demolition was heavily concentrated in the East, South and North East of the city.

\section{[insert Table 2 about here]}

Figure 2 shows London crude death rates between 1838 and 1910. The overall decline is evident, despite the spikes due to cholera outbreaks in the 1840s, 1850s and 1860s. Nevertheless, as Meen et al (2016) show, despite the concentration of policy on the poorer eastern districts, there is little evidence that death rates in these areas fell at a faster rate than the average. There are a number of possible explanations; first, crude death rates take no account of the age structure of the population. Poorer areas may contain higher proportions of the elderly and young. Second, policy might reinforce patterns of social disadvantage through the public housing programmes which replaced the slum clearances. Third, death rates may remain high because of (non-housing) area characteristics, such as high levels of pollution or the underlying industrial structure. The East End was particularly endowed with noxious industries. Fourth, as Cheshire et al (2014) emphasise, local areas within cities are subject 
to residential sorting. Therefore, poorer districts may continue to experience higher death rates simply because low-income and low-skilled households are forced or choose to live in the areas with the worst conditions.

\section{[insert Figure 2 about here]}

It is also useful, in the light of the literature review above, to examine the effects of World War 2 bombings on London. Table 3 shows that the destruction was not uniform with the City and East End districts particularly heavily hit. Stepney, for example, lost more than a quarter of its dwelling stock, but note that in most cases the population loss, through displacement, heavily exceeded the loss of dwellings and the War was, in fact, a major factor in the decline in overcrowding that had long been a characteristic of the area.

Technology (the growth of the railways), wars, and public policy are potential factors affecting longrun changes in spatial patterns of housing, local poverty and segregation. Furthermore, we have suggested that the spatial scale of analysis influences the results - broad scale analysis may disguise subtle changes, because of high local mobility. These issues are explored further in Section 5, but, first, this requires the construction of an appropriate data set of social status in late $19^{\text {th }}$ century Inner London with comparable indicators for the $21^{\text {st }}$ century.

\section{[insert Table 3 about here]}

The starting point is an analysis of the persistence of local area social status, using a sample of individuals living in London, taken from the 1881 census; the 1881 census is particularly valuable since digitised unit records are available from the UK Data Archive and is the only complete census available in this form. The unit records identify exact addresses, along with additional key information, such as occupation, allowing the construction of social status measures. Importantly, through detailed study of $19^{\text {th }}$ century maps, the addresses can be matched to their current locations and, hence, 1881 measures of Census Output Areas (or Lower and Medium Layer Super Output Areas) can be compiled consistent with modern boundaries. To construct the sample, the London $19^{\text {th }}$ century parishes are divided into five broad groups - North, South, East, West and Central - and are shown in Appendix 2; half of the parishes in each group are randomly sampled and, from these, 210 household heads are taken from each group (254 was taken from the larger southern group). Each head is required to be male and between the ages of 18 and 35; the occupations of immediate neighbouring heads, (living 
either side or in the same house) are also taken and are not required to conform to the age/gender requirements. Overall, this provides information on 6,430 heads, covering 201 modern Middle Layer Super Output Areas (MSOAs), out of a total of 394 MSOAs in inner London. The official 1950 occupational classification is used to allocate all 1881 household heads into one of five social classes (See Long 2005).

Class (i) - professional occupations; Class (ii) - intermediate occupations; Class (iii) - skilled occupations; Class (iv) - partly skilled occupations; Class (v) - unskilled occupations.

Table 4 shows the break-down of the sample by social status. Class (iii) dominates in all areas with approximately $57 \%$ of heads falling into this category. The absolute numbers and shares in Class (i) are small, but are heavily concentrated in the West and better parts of the central zone. Furthermore, all zones have significant numbers of residents in Classes (iv) and (v). Nevertheless, the greater concentrations of Class (v) in the East (24\%) and South (19\%), compared with the London average of $16 \%$, is noticeable. A similar classification is required for the 2001 census; the shares in each class in the comparable MSOA can be taken directly from the census, but the social status of different occupations changes over time and the 2001 census employs a different Socio-Economic Group Classification. Nevertheless, there is a strong correlation between the current classifications 'semiroutine and routine' occupations and the former social classes (iv and v). Thus the shares of households in Classes (iv) and (v) in both 1881 and 2001 can be constructed on a broadly comparable basis. A final complication is that the share of workers in (iv) and ( $v$ ) for London as a whole has changed between 1881 and 2001 (from 23\% to 12.5\%) and so values are standardised.

\section{[insert Table 4 about here]}

\section{Modelling Local Social Dynamics, 1881-2001}

As a simple intial test, equation (1) examines the relationship between social status in 1881 and 2001; in the recent literature, time-series analysis of population persistence has often been based on unit root tests (see Davis and Weinstein 2002), but the equation here looks at spatial persistence for the highest social classes ( $\mathrm{i}$ and ii) and the lowest classes (iv and v). However, equation (1) indicates that any correlation across the 201 sampled MSOAs is, at best, weak, for the areas of high status and nonexistent for the most deprived areas and this may cause some surprise; it could be, for example, a 
result of the sampling methods or the changes to the occupational classifications. On first reading, the results are consistent with cyclical processes of neighbourhood decline and renewal, although the modelling framework says little about the processes of change themselves. From a policy perspective, however, it matters not only whether change is cyclical, but also whether other determinants may inhibit adjustment and give rise to local incidences of persistent poverty and affluence. As noted earlier, there were a series of major shocks - both temporary and permanent - that led to change over 120 years that can be revealed by a closer inspection of the data.

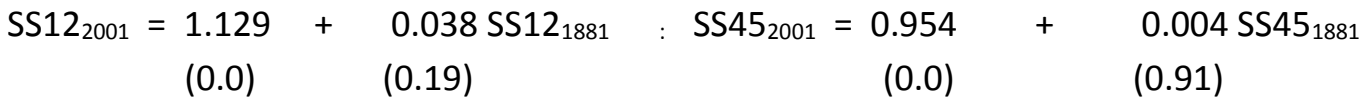

p-values in brackets

\begin{tabular}{|c|c|}
\hline SS122001 & $\begin{array}{l}=\text { share of heads in social classes (i) and (ii) in each MSOA relative to the total } \\
\text { proportion across the MSOAs in those classes in } 2001 .\end{array}$ \\
\hline SS12 1881 & $\begin{array}{l}=\text { share of heads in social classes (i) and (ii) in each MSOA relative to the total } \\
\text { proportion across the MSOAs in those classes in } 1881 .\end{array}$ \\
\hline SS452001 & $\begin{array}{l}=\text { share of heads in social classes (iv) and ( } v \text { ) in each MSOA relative to the total } \\
\text { proportion across the MSOAs in those classes in } 2001 .\end{array}$ \\
\hline SS451881 & $\begin{array}{l}=\text { share of heads in social classes (iv) and ( } \mathrm{v} \text { ) in each MSOA relative to the total } \\
\text { proportion across the MSOAs in those classes in } 1881 .\end{array}$ \\
\hline
\end{tabular}

Table 5 takes the 201 sampled MSOAs in 1881 and divides them into social status quartiles, based on the proportion of heads in classes (iv) and (v), so the concentration is on those in the lower classes rather than the higher classes, since the numbers involved are larger (see Table 4). Their ranking, again in quartiles, is then also calculated for the 2001 census, allowing us to examine the extent to which the MSOAs move across the quartiles. Since the interest is in the dynamics of change, we examine particularly those MSOAs that remain in the same quartile (notably the top and bottom quartiles) and those that experienced particularly large changes, either from the top to bottom quartiles or vice versa. The 51 areas that fall into these categories are shown in the table. Therefore, for example, MSOA Camden 010 was in the highest status quartile in both 1881 and 2001, having small proportions of heads in Classes (iv) and (v); Hackney 019 had high proportions of the poorest classes in both years; Hammersmith and Fulham 011 moved from low to high status, whereas Hackney 010 experienced a sharp decline in standing.

The table also shows the relationship with housing tenure, i.e. the proportion of dwellings in each area in the social rented sector, measured in 2011. On average, in MSOAs that were disadvantaged in both 
years, social housing comprised $54 \%$ of the housing stock in 2011 , compared with only $16 \%$ for those remaining in the most advantaged MSOAs. Furthermore, for those areas experiencing major decline between the years, on average social housing comprised $58 \%$ of the dwelling stock, compared with $13 \%$ for those experiencing the largest improvements. Prima facie, there is evidence that changes in deprivation are highly associated with tenure. As argued in Nygaard and Meen (2013), public housing often replaced slums; although the post-war expansion in public housing was originally primarily allocated to skilled working-class households, the subsequent growth in owner-occupation and later allocation priorities for public housing have contributed to a locking in of the $19^{\text {th }}$ century status. Nevertheless, overall, the data in the table suggest that, at fine spatial scales, there has been considerable movement in area status over the 120 years - perhaps more than the literature has previously suggested.

\section{[insert Table 5 about here]}

Examining the data in detail reveals more nuanced changes or differences within boroughs ${ }^{2}$. As examples, first, $73 \%$ of the dwelling stock in the North Kensington MSOA, Kensington and Chelsea 002, in 2011 was social housing and the MSOA was in the lowest status category in both 1881 and 2001; we have already discussed this in the context of Grenfell Tower, but it illustrates the persistence of concentrated poverty adjacent to affluence.

Second, Westminster 008 provides an example of $19^{\text {th }}$ diversity, whose status improved considerably by 2001 . In the $19^{\text {th }}$ century it contained workers' housing, a mortuary and a work house, but it also included large villas surrounding Lord's Cricket Ground and adjoined Regents Park. Its mixed nature can also be identified in Booth's poverty maps, where there are both "yellow" (wealthy) streets and "blue" (very poor) streets. It might also be noted that Octavia Hill's first development in Paradise Place took place in a neighbouring MSOA. Third, Tower Hamlets 027 shows the effects of the redevelopment of the docks in the late $20^{\text {th }}$ century under the London Docklands Development Corporation. The area lies next to Tower Bridge and St Katharine Dock, now both prime residential sites, but areas of high poverty in the $19^{\text {th }}$ century. Nevertheless, many areas of Tower Hamlets did not change status typically these are areas that lie further away from the river; these are shown in Table 5. Southwark 008 also lies in the docklands - in this case south of the river - and the improvement again reflects

\footnotetext{
${ }^{2}$ This also allows us to provide more information on whether the samples are truly representative of the area statuses.
} 
the influence of the Development Corporation, notably the construction of luxury apartments in the former Surrey Docks.

Fourth, Table 5 shows that Hackney is particularly highly represented amongst those that declined in status. In the late $19^{\text {th }}$ century, the area was fairly well-to-do and this is supported by the Booth maps. The development of the railways and housing sub-division contributed to gradual decline, including the quality of the housing stock. Large tracts of Hackney 010 were replaced by tower blocks in the late 1960s, removing terraced housing and semis originally built for the middle class. War-time bomb damage also facilitated the building of council housing. Of the Hackney MSOAs now in the bottom quartile, Hackney 010 in fact has the lowest proportion of social housing at $47 \%$ of the dwelling stock, whereas Hackney 019 has $68 \%$.

The descriptive analysis suggests slum clearances and the construction of social housing estates, railway development, wars and technology all have significant effects over long periods, but they are just examples and at least some of these developments can be more formally modelled for the full sample of MSOAs. Using a probit approach, we estimate the probability that any MSOA will change status over the 120 years. The dependent variable takes a value of one if the share of social class iv and $v$ residents in the MSOA changes to a different social status quartile and zero otherwise $\mathrm{e}^{3}$. As examples, from Table 5, Camden 010 and Hackney 019 were in the same social status quartiles (in terms of Class iv and $v$ residents) in both years and so the dependent variable takes a value of zero for these MSOAs. But Hammersmith and Fulham 011 and Hackney 010 changed between the top and bottom quartiles and, therefore, the dependent variable has a value of one. More generally any MSOA that stays in the same quartile (not just the top or bottom) in 1881 and 2001 takes zero and those that change a value of one. Since the results may be asymmetric, separate equations are estimated for the processes of improvement and worsening of neighbourhood status. The model is given by (2) and includes a range of different potential influences on changing status, including housing indicators, distance, transport, land use, and area diversity.

$$
\operatorname{Pr}(Y=1 \mid X)=\Phi\left(X^{\prime} \beta\right)
$$

\footnotetext{
${ }^{3}$ Robustness checks included setting the dependent variable to unity only if the MSOA moves more than one quartile, on the grounds that changes to an adjacent quartile might simply reflect the sampling. This alternative did not affect the results qualitatively and, so, are not reported here.
} 
where $\Phi$ is the standard normal cumulative distribution function and the vector of regressors $\left(X^{\prime}\right)=$ [HERF, SLUM, ADJ, BUILD, NONDOM, ROAD, PATH, RAIL, GARDEN, GREEN, WATER, In(DIST), $\ln (D I S T S Q), \ln (T U B E)]$.

\section{HERF}

SLUM

$A D J$

$B U I L D$

NONDOM

$R O A D$

PATH

RAIL

GARDEN

GREEN

WATER

DIST

DISTSQ

TUBE
= 1 if MSOA changes status quartile between 1881 and 2001; = 0 otherwise

$=$ Inverse Herfindahl-Hirschman Index.

= Proportion of the MSOA undergoing slum clearance between 1860 and 1975.

$=$ Proportion of Class (i) and (ii) heads, alternatively (iv) and (v), in adjacent MSOAs.

$=$ Proportion of the MSOA land area comprising residential buildings.

= Proportion of the MSOA land area comprising non-domestic buildings.

= Proportion of the MSOA land area comprising roads.

= Proportion of the MSOA land area comprising paths.

= Proportion of the MSOA land area comprising railways.

= Proportion of the MSOA land area comprising gardens.

= Proportion of the MSOA land area comprising green fields and parks.

= Proportion of the MSOA land area comprising water and rivers.

$=$ Distance to the centre of London in $\mathrm{km}$.

$=$ Squared distance to the Centre of London.

$=$ Distance to the nearest tube station in $\mathrm{km}$.

the equations also include dummy variables for the five zones.

We have already stressed the correlation between status and housing tenure, but, because of endogeneity, the current tenure proportions cannot be used - an improvement in status may lead to a higher proportion of ownership rather than the other way round; a better indicator is the proportion of the MSOA that has been covered by slum clearances between 1860 and 1975 (see Table 2). Slum clearances declined after the 1970s.

The distance indicators are an attempt to capture the impact of suburbanisation. Furthermore, nearness to a tube station (as the network stood in 1908) may have attracted high status households. The remaining physical neighbourhood indicators attempt to measure, for example, the attractiveness of living close to rivers and green spaces. In the examples above, the areas of Tower Hamlets and Southwark that improved most lay close to the Thames and were heavily influenced by the London Docklands Development Corporation. Note that these are measured in 2001 (due to an absence of 1881 information), although river frontages, for example, are unlikely to have changed significantly.

The model also tests the influence of class concentrations and contiguity. The concentration of class heads in 1881 is measured by the inverse of the Herfindahl-Hirschman Index $\left(\frac{1}{\sum_{i=1}^{N} s_{i}^{2}}\right)$, where s= share of heads in each social class and $(N)$ is the five classes. A higher value indicates a socially more diverse area. Contiguity to areas of low or high status in the $19^{\text {th }}$ century may also affect the probability of subsequent development. Therefore $A D J$ represents the status, in 1881, of contiguous MSOAs; for 
improving areas, this is measured by the proportion of Class (i) and (ii) heads in contiguous areas, whereas for declining MSOAs it is measured by the proportion of Class (iv) and (v) heads in adjacent locations. The idea is that if neighbouring areas are already relatively high status, there may be spill over improvements over time.

Final results are shown in Table 6; the first set refer to those MSOAs whose relative status has improved between 1881 and 2001 and the second to those whose status has declined ${ }^{4}$. In general, the results conform to prior expectations, but some of the findings should be highlighted since they are important for policy; the implications are particularly evident for those areas that improved over the 120 years and they provide information on the factors that constrain success.

\section{[insert Table 6 about here]}

First, the results show clearly that the slum clearance programmes that took place from the mid-19 century onwards hindered improvements in area social status. This is consistent with the view that the estates that replaced the slums also locked-in the pre-existing social structure, at least as measured by the distribution in 2001, although not necessarily in terms of the status distribution at the time the dwellings were constructed. As noted above, new public construction was originally targetted at skilled working-class households. Persistence in such cases was the result of a path dependence in institutions, or the spatial expression of public policy. Although the policy frequently led to reduced area population density, other dynamics of area change were weakened.

Second, and controlling for other types of area shocks, more diverse (mixed) areas in 1881 were more likely to improve their social status over time and less likely to worsen. This is consistent with results shown in Meen (2009), which examined the nature of non-linear poverty traps; areas with very high levels of poverty are less likely to reach take-off points for development.

This is further highlighted by the third finding on the importance of status in contiguous areas improvements were more likely where neighbouring areas had high proportions of Class (i) and (ii) households in 1881, although high proportions of Class (iv) and (v) does not have a similar effect on the probability of worsening. It is important to stress that since MSOAs are based on administrative

\footnotetext{
${ }^{4}$ Note that in each case the number of observations is equal to 201 ; this is because, in the first case, the dependent variable is set to zero if the area either remained in the same quartile or worsened and, in the second case is set to zero if the area remained in the same quartile or improved. The dependent variable takes a value of one otherwise.
} 
boundaries rather than underlying household behaviour, spillovers between locations are always likely to occur. However, the Grenfell area illustration also highlights that this process may be inhibited by policy or institutional shocks, e.g. the incidence of slum clearance.

Fourth, there is little evidence that the physical environment has a strong effect on improving areas, but there is evidence that proximity to environmental amenities, such as (clean) water and green space, prevents areas from declining, consistent with the impact of the London Docklands Development Corporation and income elastic demand for natural amenities. Finally, the distance indicators suggest that improvements were less likely to occur further away from central London and in locations close to railways, but the development of the tube network acted as an attractor.

In combination the results show that, over long periods, dynamic housing market change in London is common, but that the processes of change are asymmetric and conditioned, sometimes suspended, by processes of path dependence, social interactions and institutions.

\section{Policy Implications and Conclusions}

The conventional wisdom is that the relative social positions of local urban areas are highly persistent, limiting the scope for policy action and there is considerable support for this view. Nevertheless, local areas do exhibit change; these changes are partly attributable to aggregate population dynamics across cities, to advances in technology, such as transport, and also to the effects of temporary shocks, such as wars. In general, where small areas are considered, long-run changes are likely to be greater, because individuals are more mobile over short than long distances.

However, these major events take place rarely compared to the short-term cyclical fluctuations that affect housing markets. Although this paper argues that change in local social status does occur, it is worth stressing that we require 120 years of data to identify key events that are likely to induce change. Analyses over, say, twenty or thirty years or over the even shorter horizons used in policy are unlikely to reveal the processes that lead to change. Grenfell Tower is an event of sufficient magnitude that significant changes in social housing policy are expected to occur, but such events are rare. More commonly, direct housing policy interventions are modest and are unlikely to lead to fundamental 
change. Housing policy operates within the financial constraints of wider macroeconomic policies and, typically, plays a secondary role.

But this paper points to an additional wider set of constraints; both neo-classical economic theory and models concerned with social interactions lead to the conclusion that segregated spatial patterns for households are the most likely outcome - formally segregation is a stochastically stable state - and attempts by policy to promote social mixing are fighting against strong market forces. Furthermore, since policies are path dependent, the decisions of even the most reforming governments are constrained by the actions of past governments. Therefore, macroeconomic constraints, social interactions and path dependence all contribute towards the persistence of neighbourhood patterns. The events of a hundred years ago are still relevant to policy today.

It is important that the limitations of direct housing policy action are recognised but, by taking a longrun perspective, it is possible to recognise those events that promote or hinder change and are relevant to current policy. Even with data at two points in time, we have shown in this paper that a range of factors have played a role; these include the extent of status concentration in the late $19^{\text {th }}$ century, transport networks and suburbanisation, and proximity to rivers and green spaces. Given the nature of the data set, we have not examined explicitly the role of wars in inducing changes, although Meen et al (2016) show the impact of the Second World War on the location of migrants within London. But, here, the focus of attention has been on the nature of the housing stock, the tenure distribution and the effects of slum clearance programmes that have taken place since the mid-19 century. Although the aim of slum clearances was to improve housing conditions for low-income households, in fact, the empirical evidence suggests that they have, to an extent, locked in pre-existing patterns of social status, rather than promoting more integrated communities.

The fact that the empirical results only consider two points in time imposes constraints on the conclusions; areas may have undergone cyclical changes between those points. Notting Hill provided an example; this was originally constructed as a high-class area in the mid- $19^{\text {th }}$ century, went into decline in the mid-20 $20^{\text {th }}$ century as the population of inner London declined, but subsequently recovered as an area of high status as the inner London population rose again. This issue provides a spur to further research; furthermore, there is a strong case for extending the analysis outside London. This is a data-intensive exercise, but the insights that it reveals for current policy provides an incentive. 
This paper has further suggested a more nuanced understanding of long-term intra-urban social, economic and physical development patterns. This should, at the very least, draw on the key mechanisms of path dependency, social interactions and institutional analysis, and the stylsed facts emerging from this to inform and pose conceptual and practical challenges to policy makers proposing significant housing and neighbourhood development change. One interpretation of the evidence we have considered is that past episodes of attempts to improve housing quality and clear slums evidently did not take sufficient account of forces resisting the desired policy aims. Contemporary policy makers should look back in order to help them think more realisitically about what they might achieve for the future.

\section{References}

Arthur, W (1994) Increasing Returns and Path Dependency in the Economy. University of Michigan Press: Ann Arbor: Mi.

Baumont, C and Huriot, J-M (1998) 'The Monocentric Model and After', Recherches Economiques de Louvain, 64 (1), pp. 23-43.

Bosker, M, Brakman, S, Garretsen, H, and Schramm, M (2007) 'Looking for Multiple Equilibria when Geography Matters: German City Growth and the WWII Shock', Journal of Urban Economics, 61, pp. 152-169.

Brueckner, J (2000) 'Urban Growth Models with Durable Housing: An Overview', in J-M Huriot and J-F Thisse (eds) Economics of Cities: Theoretical Perspectives. CUP: Cambridge.

Cannadine, D. (1977), 'Victorian Cities: How Different?' Social History, 2(4): 457-482.

Cheshire, P, Nathan, M, and Overman, H (2014) Urban Economics and Urban Policy: Challenging Conventional Policy Wisdom. Cheltenham. Edgar Elgar Publishing Limited.

Cheshire, P and Shepherd, S (1995) 'On the Price of Land and the Value of Amenities', Economica, 62, pp.247-67.

Cheshire, P and Shepherd, S (1998) 'Estimating the Demand for Housing, Land and Neighbourhood Characteristics', Oxford Bulletin of Economics and Statistics, 60 (3), pp. 357-82.

David, P (2007) 'Path Dependence - A Foundational Cpncept for Historical Social Science', Cliometrica - The Journal of Historical /economics and Econometric History, 1 (2), pp.91-114.

Davis, D, and Weinstein, D (2002) 'Bones, Bombs, and Break Points: the Geography of Economic Activity', American Economic Review, 92(5), pp. 1269-1289.

Department of the Environment (1977) Housing Policy Technical Volume Part 1. London. HMSO. 
Dincecco, M, and Onorato, M (2013) 'Military Conflict and the Economic Rise of Urban Europe', Working Paper 7/2013, Institute for Advanced Studies, Lucca.

Dorling, D., Mitchell, R., Shaw, M., Orford, S., and S. Davey Smith (2000), 'The Ghost of Christmas Past: Health Effects of Poverty in London in 1896 and 1991', British Medical Journal, 321: 23-30.

Easterly, W, Freschi, L, and Pennings, S (2015) 'A Long History of a Short Block: Four Centuries of Development Surprises on a Single Stretch of a New York City Street'. Mimeo. http://www.greenestreet.nyc/paper. Accessed, 29 July 2015.

Galster, G (2010) 'Neighbourhood Social Mix: Theory, Evidence and Implications for Policy and Planning', paper presented at the 2009 international workshop at Technion University: 'planning for/with People'.

Hill, O (1866) Homes for the London Poor. Reprinted from the Fortnightly Review and MacMillan's Magazine. Prnted by Amazon.

Hornbeck, R. and Keniston, D. (2017) 'Creative destruction: barriers to urban growth and the Boston great fire of 1872', American Economic Review, 107(6):1365-1398.

Jones, I (2016) London Bombed, Blitzed and Blown Up: the British Capital under Attack since 1867. Barnsley. Frontline Books.

Krugman, P (1991) 'History versus Expectations', Quarterly Journal of Economics, 106 (2), pp.651-67.

London Topographical Society (2005) The London County Council Bomb Damage Maps 1939-1945. London Topographical Society and London Metropolitan Archives. LTS Publication No. 164. London.

Manski, C (1993) 'Identification of Endogenous Social Effects: The Reflection Problem', Review of Economic Studies, 60, 531-42.

Manski, C (2000) 'Economic Analysis of Social interactions', Journal of Economic Perspectives, 14 (3), pp.115-36.

Martin, R. (2010) 'Roepke Lecture in Economic Geography - Rethinking Regional Path Dependence: Beyond Lock-in to Evolution', Economic Geography, 86 (1): 1-27.

Meen G. (2009), "Modelling Local Spatial Poverty Traps in England”, Housing Studies, 24(1): 127-147.

Meen, G, Gibb, K, Leishman, C and Nygaard, C (2016) Housing Economics A Historical Approach. Palgrave Macmillan: London.

Meen, D and Meen, G (2003) 'Social Behaviour as a Basis for Modelling the Urban Housing Market: A Review', Urban Studies, 40, pp.917-35.

Meen, G, and Nygaard, C (2011) 'Local Housing Supply and the Impact of History and Geography', Urban Studies. 48(14), pp. 3107-3124.

McDonald, J and McMillen, J (2007) Urban Economics and Real Estate: Theory and Practice. Blackwell: Oxford. 
Morrison, A. (1896), A Child of the Jago. Chicago, Academy Chicago Publishers.

Nitsch, V (2003) 'Does History Matter for Urban Primacy? The Case of Vienna', Regional Science and Urban Economics, 33. pp. 401-418.

North, D (1994) 'Economic Performance through Time', American Economic Review, (3), pp. 359-68. 84

North, D (2005) Understanding the Process of Economic Change. Princeton University Press: Princeton, NJ.

Nygaard, C, and Meen, G (2013) 'The Distribution of London Residential Property Prices and the Role of Spatial Lock-in', Urban Studies, 50(12), pp. 2535-2552.

Orford, S, Dorling, D, Mitchell, R, Shaw, M, and Davey Smith, G (2002) 'Life and Death of the People of London: A Historical GIS of Charles Booth's Inquiry', Health and Place, 8, pp. 25-35.

Pereira, A (2009) 'The Opportunity of a Disaster: The Economic Impact of the 1755 Lisbon Earthquake', Journal of Economic History, 69(2), pp. 466-499.

Ravenstein, E (1885) 'The Laws of Migration', Journal of the Statistical Society of London, 48(2), pp. 167-235.

Siodla, J. (2015) 'Razing San Francisco: the 1906 disaster as a natural experiment', Journal of Urban Economics, 89: 48-61.

Taleb, N (2018) Skin in the Game. Random House: New York.

Voigtländer, N, and Voth, H-J (2013) 'The Three Horsemen of Riches: Plague, War and Urbanization in Early Modern Europe, Review of Economic Studies, 80, pp. 774-811.

Woodward, H.B. (1906), Soils and Subsoils: From a Sanitary Point of view with Especial Reference to London and its Neighbourhood. London. HMSO. 


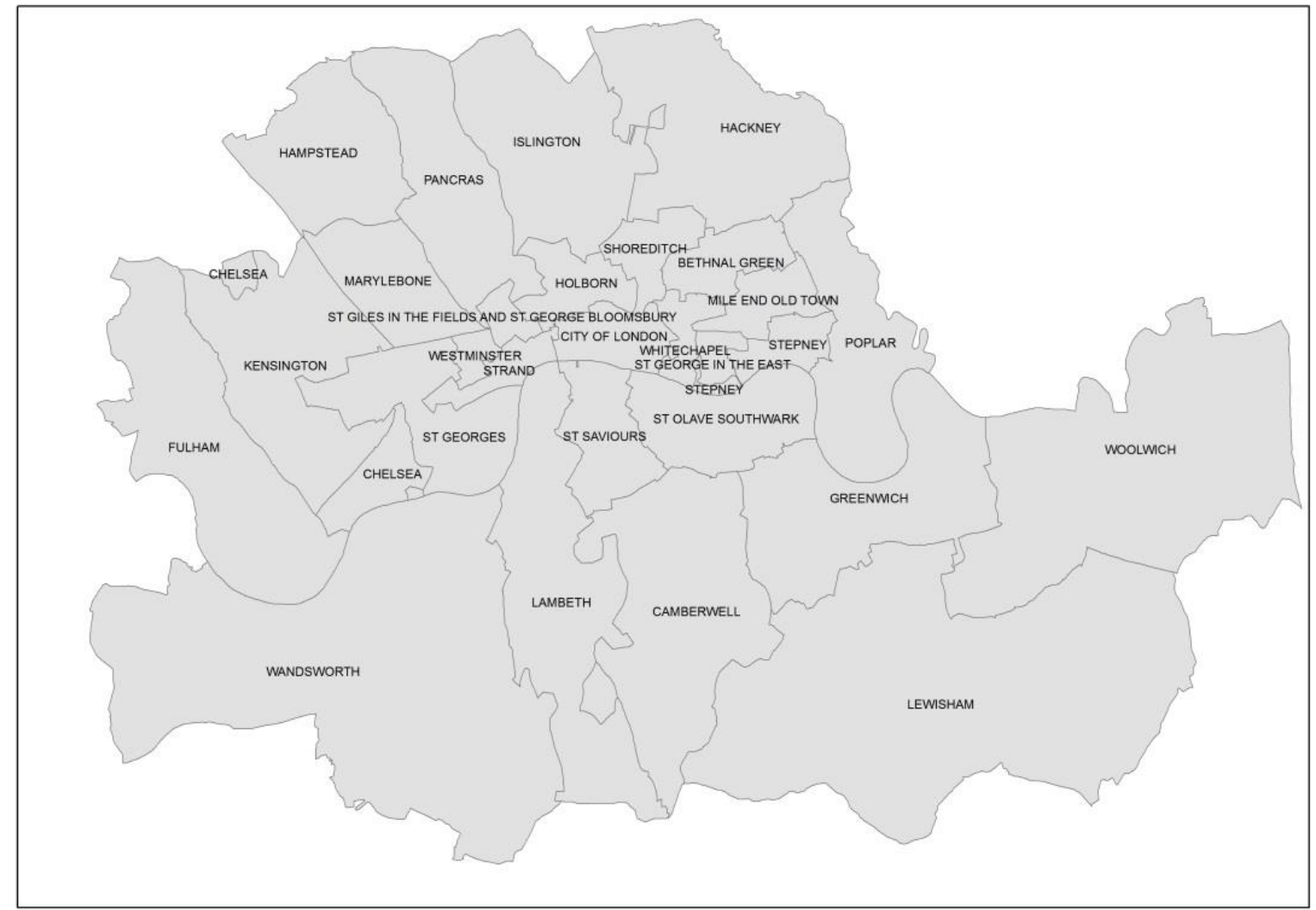

This map is based on data provided through www.VisionofBritain.org.uk and uses historical material which is copyright of Humphrey Southall/Great Britain Historical GIS/University of Portsmouth. 
Sampled parishes are denoted with an asterisk.

\begin{tabular}{|l|l|l|l|l|}
\hline Central & North & East & South & West \\
\hline Shoreditch* & Paddington & Bethnal Green & St Saviour* & $\begin{array}{l}\text { St George, Hanover } \\
\text { Square }\end{array}$ \\
\hline Clerkenwell & St Marylebone* & Whitechapel* & St George* & St James \\
\hline St Luke Old Street* & St Pancras* & $\begin{array}{l}\text { Mile End Old } \\
\text { Town }\end{array}$ & Bermondsey* & St Martin in the Fields* \\
\hline St Anne, Soho & Islington & $\begin{array}{l}\text { St George in the } \\
\text { East* }\end{array}$ & Rotherhithe* & St Margaret \\
\hline St Paul, Covent Garden* & Hackney* & Limehouse* & The Martyr & St Margaret (detached) \\
\hline St Giles in the Field* & & Poplar* & Christ Church, Southwark & Chelsea* \\
\hline St George, Bloomsbury & & $\begin{array}{l}\text { Christchurch, } \\
\text { Spitalfields }\end{array}$ & St Thomas, Southwark & Kensington* \\
\hline $\begin{array}{l}\text { St George the Martyr, } \\
\text { Queen's Square }\end{array}$ & & $\begin{array}{l}\text { Mile End New } \\
\text { Town* }\end{array}$ & St Olave, Southwark* & St John* \\
\hline Gray's Inn & $\begin{array}{l}\text { Holy Trinity } \\
\text { Minories* }\end{array}$ & St John, Horsleydown & \\
\hline Lincoln's Inn & Tower Liberty & & \\
\hline Liberty of the Rolls & & $\begin{array}{l}\text { St Katherine by } \\
\text { the Tower }\end{array}$ & & \\
\hline Temple* & $\begin{array}{l}\text { St Botolph } \\
\text { Without, } \\
\text { Aldgate* }\end{array}$ & & \\
\hline St Clement Danes* & & St John, Wapping & & \\
\hline Precinct of the Savoy* & & St Paul, Shadwell & & \\
\hline St Mary Le Strand & & Ratcliff* & & \\
\hline Liberty of Saffron Hill* & & & & \\
\hline St Sepulchre & & & & \\
\hline Charterhouse* & & & & \\
\hline Liberty of Norton & & & & \\
\hline Folgate* & & & & \\
\hline St Andrew, Holborn* & & & & \\
\hline St James, Clerkenwell & & & & \\
\hline St John, Clerkenwell* & & & & \\
\hline
\end{tabular}


Table 1. Net Additions to the Housing Stock and Population/Dwellings, 1871-1901

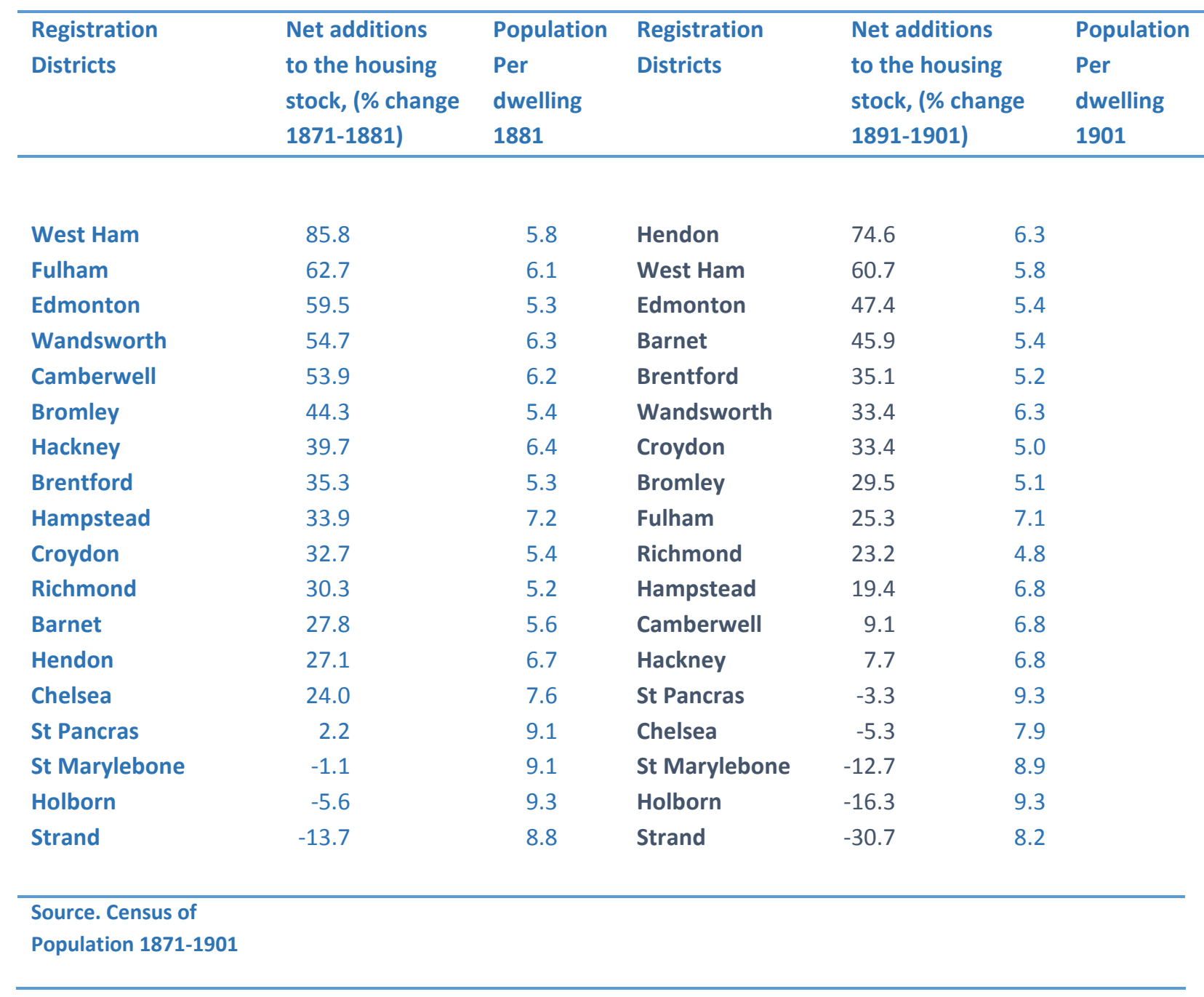


Table 2. Slum Clearance Activity in London 1860-1973

\begin{tabular}{ccccc}
\hline Period & Number & Average area $\left(\mathbf{m}^{\mathbf{2}}\right)$ & St. Dev. $\left(\mathbf{m}^{\mathbf{2}}\right)$ & Total area $\left(\mathbf{m}^{\mathbf{2}}\right)$ \\
\hline Pre-1890 & 31 & 7,390 & 6,993 & 229,090 \\
1890s Acts & 34 & 7,942 & 13,830 & 270,028 \\
1930s Acts & 207 & 6,890 & 7,471 & $1,426,230$ \\
Post-war (1945-54) & 96 & 4,634 & 7,068 & 444,864 \\
1955-1964 & 587 & 3,482 & 4,451 & $2,043,934$ \\
1965-1975 & 235 & 4,118 & 5,456 & 967,730 \\
Total & $\mathbf{1 , 1 9 0}$ & $\mathbf{4 , 5 2 3}$ & $\mathbf{6 , 1 5 8}$ & \\
& & & & \\
& & & & \\
\hline
\end{tabular}

Table 3. The London Registration Districts and the Second World War

\begin{tabular}{|c|c|c|c|c|}
\hline & $\begin{array}{c}\text { Houses } \\
\text { Destroyed* } \\
(\%)\end{array}$ & $\begin{array}{l}\text { Killed/Seriously } \\
\text { Wounded } * *\end{array}$ & $\begin{array}{c}\text { V1 } \\
\text { Rockets*** }\end{array}$ & $\begin{array}{c}\text { Population change } \\
\text { 1939-1951 } \\
(\%) \\
\end{array}$ \\
\hline City of London & 38 & 6.21 & 25.6 & -41.5 \\
\hline Bethnal Green & 12 & 0.45 & 1.8 & -35.3 \\
\hline Chelsea & 6 & 1.58 & 1.0 & -8.0 \\
\hline Finsbury & 12 & 0.81 & 1.1 & -35.8 \\
\hline Hackney & 14 & 0.32 & 2.5 & -16.5 \\
\hline Hampstead & 1 & 0.33 & 1.1 & 5.5 \\
\hline Holborn & 17 & 1.52 & 2.2 & -25.7 \\
\hline Islington & 6 & 0.60 & 0.7 & -18.2 \\
\hline Kensington & 7 & 0.43 & 1.8 & -2.29 \\
\hline Lambeth & 18 & 1.01 & 4.1 & -15.0 \\
\hline Poplar & 21 & 1.16 & 7.0 & -43.9 \\
\hline St Pancras & 7 & 0.84 & 1.7 & -22.2 \\
\hline Shoreditch & 21 & 1.47 & 1.9 & -41.9 \\
\hline Southwark & 11 & 1.17 & 2.0 & -31.1 \\
\hline Stepney & 26 & 0.66 & 4.0 & -49.9 \\
\hline Westminster & 17 & 1.74 & 4.4 & -19.5 \\
\hline
\end{tabular}

Source. London Topographical Society (2005)

* Houses destroyed, demolished and damaged as \% of 1939 total

** Residents killed and seriously wounded as \% of 1939 population

*** V1 rockets per 10,000 of 1944 population 
Table 4. Household Heads in Each Zone by Social Class, 1881 (numbers and percentages)

\begin{tabular}{lccccccc}
\hline & $\begin{array}{c}\text { Total } \\
\text { Number }\end{array}$ & $\begin{array}{c}\text { Class } \\
\text { (i) }\end{array}$ & $\begin{array}{c}\text { Class } \\
\text { (ii) }\end{array}$ & $\begin{array}{c}\text { Class } \\
\text { (iii) }\end{array}$ & $\begin{array}{c}\text { Class } \\
\text { (iv) }\end{array}$ & $\begin{array}{c}\text { Class } \\
\text { (v) }\end{array}$ & $\begin{array}{c}\text { Sum } \\
\text { (iv \&v) }\end{array}$ \\
\hline North & 1328 & 6 & 119 & 838 & 206 & 160 & 366 \\
West & 1211 & 46 & 158 & 658 & 197 & 153 & 350 \\
South & 1248 & 11 & 142 & 665 & 199 & 231 & 430 \\
East & 1071 & 4 & 143 & 518 & 151 & 255 & 406 \\
Central & 1573 & 16 & 144 & 965 & 251 & 197 & 448 \\
\hline All Areas & 6430 & 82 & 705 & 3644 & 1004 & 995 & 1999 \\
\hline & Percentages & & & & & & \\
\hline North & 100 & 0.5 & 9.0 & 63.1 & 15.6 & 12.0 & 27.6 \\
West & 100 & 3.8 & 13.0 & 54.3 & 16.3 & 12.6 & 28.9 \\
South & 100 & 0.9 & 11.4 & 53.3 & 15.9 & 18.5 & 34.5 \\
East & 100 & 0.4 & 13.4 & 48.4 & 14.1 & 23.8 & 37.9 \\
Central & 100 & 1.0 & 9.2 & 61.3 & 16.0 & 12.5 & 28.5 \\
All Areas & 100 & 1.3 & 11.0 & 56.7 & 15.6 & 15.5 & 31.1 \\
\hline
\end{tabular}

Source. 1881 Census of Population and authors' calculations. 
Table 5. Changes in MSOA Social Status 1881-2001

\begin{tabular}{|c|c|c|c|}
\hline $\begin{array}{l}\text { (a) Lowest proportions of } \\
\text { class (iv) \& (v) in both years }\end{array}$ & $\begin{array}{l}\text { \% social } \\
\text { housing in } \\
2011\end{array}$ & $\begin{array}{l}\text { (b) Highest proportions of } \\
\text { class (iv) \& (v) in both years }\end{array}$ & $\begin{array}{l}\text { \% social housing } \\
\text { in } 2011\end{array}$ \\
\hline & & & \\
\hline Camden 010 & 20.3 & Hackney 019 & 67.6 \\
\hline Hammersmith and Fulham 010 & 24.9 & Kensington and Chelsea 002 & 72.5 \\
\hline Hammersmith and Fulham 014 & 16.1 & Lambeth 006 & 54.3 \\
\hline Islington 017 & 26.0 & Lambeth 031 & 49.3 \\
\hline Islington 020 & 28.6 & Tower Hamlets 008 & 55.7 \\
\hline Kensington and Chelsea 010 & 4.0 & Tower Hamlets 009 & 40.6 \\
\hline Kensington and Chelsea 011 & 3.7 & Tower Hamlets 013 & 37.4 \\
\hline Kensington and Chelsea 020 & 9.3 & Tower Hamlets 014 & 53.8 \\
\hline Wandsworth 008 & 16.8 & Tower Hamlets 018 & 54.3 \\
\hline Wandsworth 026 & 12.2 & Tower Hamlets 020 & 60.1 \\
\hline Westminster 011 & 10.4 & Tower Hamlets 022 & 56.6 \\
\hline Westminster 013 & 27.5 & Wandsworth 002 & 36.8 \\
\hline Westminster 016 & 7.8 & Wandsworth 007 & 57.2 \\
\hline $\begin{array}{l}\text { (c) Highest proportions of } \\
\text { class (iv) \& (v) in } 1881 \text { but } \\
\text { lowest in } 2001\end{array}$ & 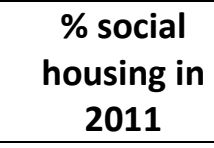 & $\begin{array}{l}\text { (d) Lowest proportions of } \\
\text { class (iv) \& (v) in } 1881 \text { but } \\
\text { highest in } 2001\end{array}$ & $\begin{array}{l}\text { \% social housing } \\
\text { in } 2011\end{array}$ \\
\hline Hammersmith and Fulham 011 & 24.8 & Hackney 010 & 47.1 \\
\hline Kensington and Chelsea 007 & 18.5 & Hackney 016 & 60.6 \\
\hline Kensington and Chelsea 016 & 5.1 & Hackney 024 & 62.1 \\
\hline Southwark 008 & 23.3 & Hackney 025 & 53.2 \\
\hline Tower Hamlets 027 & 11.6 & Hackney 026 & 55.1 \\
\hline Wandsworth 001 & 12.0 & Islington 005 & 64.0 \\
\hline Wandsworth 006 & 10.3 & Lambeth 008 & 52.3 \\
\hline Wandsworth 010 & 6.0 & Lambeth 024 & 58.5 \\
\hline Westminster 003 & 24.7 & Southwark 011 & 71.0 \\
\hline Westminster 007 & 12.4 & Southwark 015 & 67.9 \\
\hline Westminster 008 & 5.1 & Southwark 017 & 50.7 \\
\hline Westminster 017 & 11.9 & Tower Hamlets 002 & 55.4 \\
\hline Westminster 019 & 3.9 & & \\
\hline
\end{tabular}

MSOAs mentioned in the text are highlighted in bold. 
Table 6. Probit Equations for Changed Status 1881-2001

\begin{tabular}{|c|c|c|c|c|}
\hline & Improving & & Worsening & \\
\hline & Coefficient & z-value & Coefficient & z-value \\
\hline constant & 3.971 & 1.4 & 9.131 & 3.2 \\
\hline HERF & 1.011 & 5.0 & -0.989 & -5.2 \\
\hline SLUM & -0.152 & -3.7 & -0.004 & -0.2 \\
\hline$A D J$ & 0.025 & 2.2 & -0.005 & -0.5 \\
\hline$B U I L D$ & -0.021 & -0.5 & -0.119 & -2.7 \\
\hline NONDOM & -0.1 & -2.1 & -0.121 & -2.6 \\
\hline$R O A D$ & -0.016 & -0.3 & -0.036 & -0.8 \\
\hline PATH & -0.089 & -0.6 & -0.015 & -0.1 \\
\hline RAIL & -0.141 & -2.4 & -0.057 & -1.7 \\
\hline GARDEN & -0.09 & -2.2 & -0.048 & -1.2 \\
\hline GREEN & -0.037 & -1.2 & -0.066 & -2.3 \\
\hline WATER & -0.033 & -1.0 & -0.132 & -3.2 \\
\hline $\ln (D I S T)$ & -3.662 & -2.6 & -0.618 & -1.6 \\
\hline $\ln (D I S T S Q)$ & 1.452 & 3.1 & & \\
\hline $\ln (T U B E)$ & -0.329 & -2.0 & 0.013 & 0.1 \\
\hline $\mathrm{N}$ & 201 & & 201 & \\
\hline Pseudo R2 & 0.347 & & 0.249 & \\
\hline
\end{tabular}

Note: Variables that are significant at the $5 \%$ level are noted in bold. Area dummies not shown. 


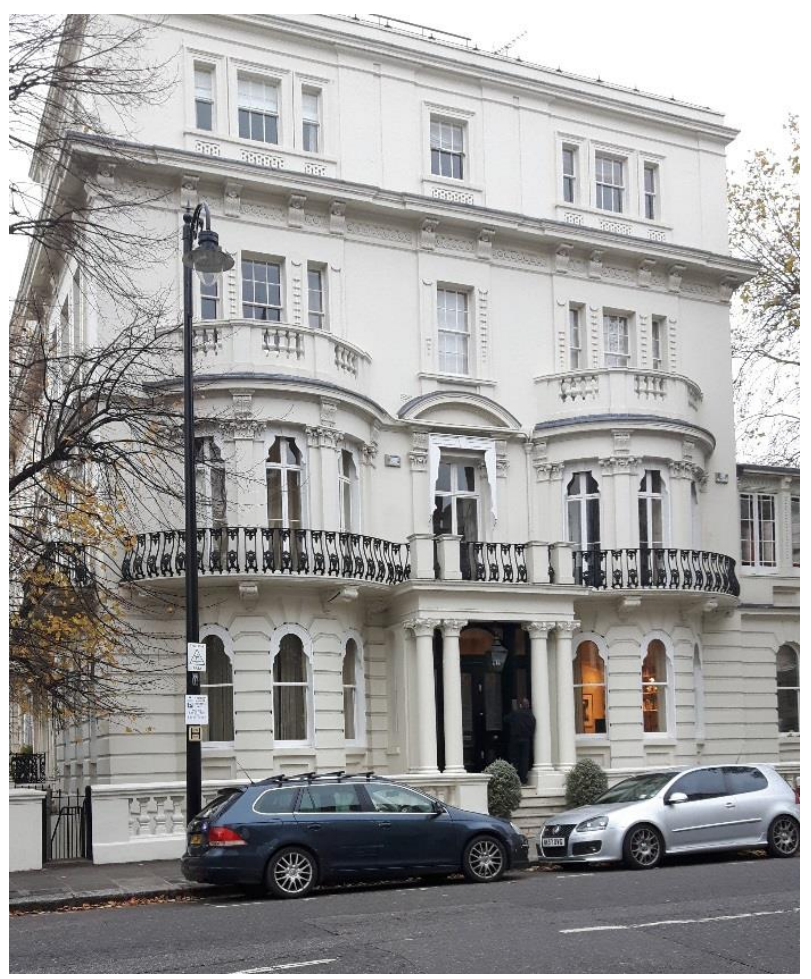

Figure 1. The Peak of Notting Hill. Source. Authors' photograph

London Crude Death Rates per 1000 of Population (1838-1910)

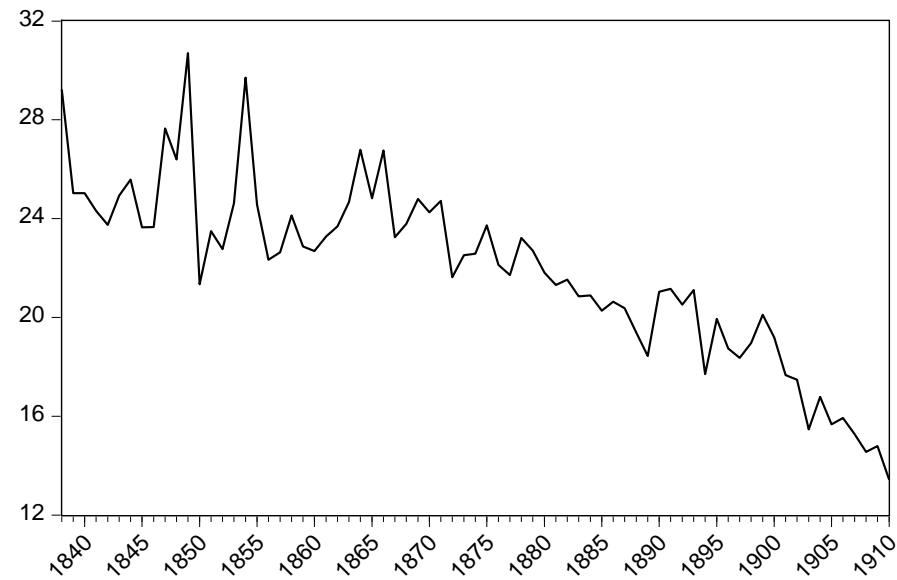

Figure 2. London-wide Death Rates 1838-1910

Source. Registrar General's Reports for England and Wales 